\title{
PROSPECTIVE WAYS OF IMPROVEMENT OF DENTAL PHOTOCOMPOSITE FILLING MATERIALS AS AN ELEMENT OF DOMESTIC DEVELOPMENT THE DENTAL CARE GOODS PRODUCTION IN UKRAINE: A REVIEW
}

\author{
Mochalov Yu. O., Keian D. M.
}

\section{INTRODUCTION}

Nowadays, the official statistical data and results of numerous epidemiological and clinical studies in Ukraine established a fact of the wide prevalence of dental diseases in the population and defects of the hard tissues of the teeth particularly. Preliminary hypotheses and approximate calculations proposed that $47,97 \%$ of the country's population need dental treatment (different kinds of teeth ${ }^{1}$ crown integrity restoring). Only 7,30\% of the young population have no dental diseases and the problem of widespread dental health decreasing exists for a long time ${ }^{2}$.

Applying medical and diagnostic measures together with preventive programs development in context of health care sector reforming were affected by sharp shortage of state funding for dental care ${ }^{3}$. Now public dental care in Ukraine is ineffective and does not solve the problem of stabilizing and reducing the incidence of dental diseases in the country ${ }^{4,5}$. Due to improvement of curative and diagnostic technologies in national dentistry, there is an intensive implementation of the latest high-value scientific technologies in practice which may increase the cost of dental care. Ukraine has a high dependence on import of dental materials, instruments, equipment, supplies and consumables (only 5,00-10,00\% on market are of

1 Мочалов Ю.О. Комплексне обгрунтування вдосконалення лікування зубів із дефектами твердих тканин в умовах розвитку імпортозаміщення пломбувальних матеріалів. Дис. д-ра мед.н. Ужгород : УжНУ, 2020. 434 с.

${ }^{2}$ Клітинська О.В., Мочалов Ю.О., Дячук К.Г. [та ін.]. Особливості поширення карієсу зубів у школярів старших класів міста Ужгород. Молодий вчений. 2015. № $10(2)$. С. 170-172.

3 Дорошенко О.О. Сучасний стан фінансово-економічного забезпечення медичної допомоги на вторинному рівні. Державне управління: удосконалення та розвиток. 2017. № 2. URL: http://www.dy.nayka.com.ua/?op=1\&z=1038.

4 Мазур І.П. Про стан та перспективи стоматологічної допомоги в Україні. Современная стоматология. 2017. № 2. С. 69-71.

5 Кононова О.В. Сучасний стан лікування карієсу та його ускладнень у населення України. Гігієна населених місиьь. 2014. № 64. С. 336-342. 
domestic origin). A lot of dental medical products are not produced in Ukraine at all ${ }^{6}$.

To date, the most common type of dental medical care in the world is the treatment of dental caries with the subsequent installation of fillings and the most used dental materials for such work are dental composite filling materials ${ }^{7,8}$. Contemporary practical dentistry has more than five decades of experience in composite filling materials using (composites of chemical, light-curing and double curing (hardening) mechanism). Using modern dental composites allows to eliminate the different defects of the teeth 'es hard tissues which allows to restore the mechanical and aesthetic functions of the teeth. The modern dental light-cured composite filling materials (resins) occupied a leading position among all restorative materials in arsenal of dentistry due to their excellent aesthetic, mechanical and technological properties 9 .

\section{Dental composite filling materials (resins): current status}

In fact, mechanical and physical properties of photocomposite materials are determined by its compounds - the main organic component are fractions of methyl-methacrylate resins which do the function of binder and plasticizer. Also, the non-organic component (mostly - grinded glass) plays a specific role in the lot of properties of dental resin. The amount of nonorganic filler, particles' size, hybridization of particles of different sizes, their configuration, as well as the composition of the organic matrix determine the mechanical properties of polymerized dental filling material, such as compressive strength, bending, rupture, flexure modulus, microhardness, X-ray contrast ${ }^{10} 11$.

6 Любченко О.В. Оценка экономической эффективности применения отечественных материалов при лечении осложненного кариеса в сравнении с импортными аналогами. Вісник проблем біології і медицини. 2015. № 2(1). С. 344-347.

${ }^{7}$ Ai M., Du Z., Zhu S. [et al.]. Composite resin reinforced with silver nanoparticlesladen hydroxyapatite nanowires for dental application. Dent. Mater. Off. Publ. Acad. Dent. Mater. 2017. Vol. 33. P. 12-22. DOI: 10.1016/j.dental.2016.09.038.

${ }^{8}$ Al-Sunbul H., Silikas N., Watts D.C. Polymerization shrinkage kinetics and shrinkage-stress in dental resin-composites. Dent Mater. 2016. Vol. 32(8). P. 998-1006. DOI: 10.1016/j.dental.2016.05.006.

${ }^{9}$ Удод О.А., Борисенко О.М. Лабораторне дослідження крайового прилягання нанофотокомпозиційного матеріалу. Вісник проблем біологї̈ $i$ медицини. 2019. № 1(1). C. 244-247.

10 Храмченко С.Н., Казеко Л.А. Композитные материалы в терапевтической стоматологии : учебно-методическое пособие. Минск : БГМУ, 2007. 20 с.

${ }^{11}$ Ástvaldsdóttir Á., Dagerhamn J., van Dijken J.W.V. [et al.]. Longevity of posterior resin composite restorations in adults - A systematic review. J. Dent. 2015. Vol. 43. P. 934-954. DOI: 10.1016/j.jdent.2015.05.001. 
By the way, modern practical dentistry still has needs to create an "ideal" composite filling material and its properties would be as close as possible to the characteristics of natural teeth. So, numerous research centers and manufacturers in different countries continue to develop dental composite materials using the latest and improved technologies. A relatively new direction separated among composite filling materials has become a class of dental composite filling materials with nano-disperse fillers. Such materials have become universal, nano-hybridization has reduced polymerization shrinkage and improved aesthetic properties.

Historically, the photocomposite dental filling materials are the result of long-lasting and numerous improvements and transformation of the cement filling materials which were begun to be used practical dentistry in XIXth century. Every modern permanent dental filling material must suit the wellknown requirements for dental filling materials ${ }^{12}$. At the end of the XIX century W. D. Miller defined the criteria and requirements for the socalled "ideal" filling material which is used to restore carious and noncarious defects of teeth hard tissues. Even in our time, with some additions and clarifications such requirements stay relevant ${ }^{13,14}$. Therefore, according to them, the dental filling material should be:

1. Resistant to various chemical influences: the properties of the material should not change under the influence of saliva, food, oral and dentine fluid.

2. Must have high strength which is associated with intense chewing load.

3 . The appearance of the filling material should mimic the natural teeth.

4. Must have sufficient abrasion resistance to various abrasive materials.

5. Must have a satisfactory edge fit which is ensured by its constant shape and volume during polymerization.

6. Must have sufficient adhesion to tooth's hard tissues or to other filling and construction materials.

7. Retain its properties (shape and volume) for a long time.

8. Should not shrink during polymerization.

9. It should be easy to use in the clinic, ie have special manipulative properties (plasticity, enough long "working time", not stick to dental modelling instruments, etc.).

10. It should not be toxic, the filling material should be safe for the tissues of the tooth and the mucous membrane of the oral cavity and should

${ }^{12}$ Kidd E., Fejerskov O. Changing concepts in cariology: forty years on. Dent Update. 2013. Vol. 40, № 4. P. 277-286. DOI: 10.12968/denu.2013.40.4.277.

13 Kim E.H., Jung K.H., Son S.A. [et al.]. Effect of resin thickness on the microhardness and optical properties of bulk-fill resin composites. Restor Dent Endod. 2015. Vol. 40(2). P. 128-135. DOI: 10.5395/rde.2015.40.2.128.

14 Николаев А.И., Цепов Л.М. Практическая терапевтическая стоматология : учеб. пособие. М. : МЕДпресс-информ, 2014. 928 с. 
not contain substances that could harm the health of the patient, doctor and another medical staff.

11. Must prevent the occurrence of secondary caries and its complications, ie have anti-carious effect.

12. X-ray contrast of the filling material should be similar to the natural tissues of the tooth or exceed it.

13. Must have a minimum thermal conductivity to provide thermal insulation of the tooth pulp in cases of hot or cold food enjoying.

14. Must have a long service life (this applies to seals and restorations) ${ }^{15,16}$.

\section{Modern dental filling materials: new agenda, chances and requests}

Anyway, in modern conditions on the dental market it is impossible to find a universal filling material that would meet all the abovementioned requirements. On the other hand, if we analyze the requirements and complaints presented by patients during the clinical work in the previous 10-15 years we can judge the growth of the average patient's requirements mostly for aesthetics of fillings and restorations of teeth, and not only for frontal but also for masticatory group of teeth.

Quite often the patient asks to replace the existing unsightly restorations and fillings containing amalgam with more modern dental works that mimic the properties of a natural tooth. Therefore, according to many experts, today the leading criterion for the quality of dental work moved to aesthetics. 15-20 years ago the main criteria of patient satisfaction dental medical care service were painlessness and functional rehabilitation of the tooth, today the high aesthetics of restoration is additionally distinguished. The reasons for this evolution of requirements and approaches may be considered among a growth of population cultural level and income level, as well as due to scientific and technological progress which provides modern dental care with an enough choice of dental composite resin materials and technologies for their application ${ }^{17,18}$.

15 Курсевич К.Е. Факторы, влияющие на цветостабильность пломбировочных материалов : вып. кв. раб. Санкт-Петербург, 2018. 53 с.

16 Ніколішин А.К. Терапевтична стоматологія : підручник для студентів стоматологічного факультету вищих медичних навчальних закладів IV рівня акредитації. Вінниця : Нова Книга, 2012. 680 с.

17 Алексеева Е.Г., Кравцов Р.В. Использование суперопаковых оттенков композитного материала "Jen-Radiance" для реализации минимально инвазивной эстетической реставрации зубов фронтального участка. Современная стоматология. 2016. № 2. С. 20-22.

${ }^{18}$ Безвушко Е.В., Шпотюк О.О. Оцінка застосування пломбувальних матеріалів для відновлення твердих тканин постійних зубів у дітей. Вісник Української медичної стоматологічної академії. 2017. Т. 17. Вип. 3. С. 191-194. 
In modern dentistry we also can see an evolution of the opinion of dental practitioners about the aesthetics of teeth fillings-restorations. In practice, the category of aesthetics, as originally belonging to art and art history, has become a full-fledged daily definition which is used by almost every dentist. Therefore, process of tooth crowns parts restoring with the most approximation to the natural transparency of the tooth, imitation of its natural appearance by reproducing a whole palette of shades, cutting edge and microrelief became relevant. That's why dental medical care is becoming more aesthetic and leading modern trends in teeth restorations styles are: perfect repetition of the natural appearance of the dentition, a complete imitation of the anatomical shape and optical properties of natural teeth ${ }^{19,20}$.

Given the growing array of scientific, medical and clinical information on the restoration of the aesthetics of the dentition, to streamline approaches and a common understanding of the problem, I.K. Lutskaya identified the following principles of modern aesthetic dentistry ${ }^{21,22}$ :

1. Correspondence of the appearance of the restoration to the natural parameters of the natural tooth (in color, shape, macro- and microrelief).

2. Optimal therapeutic effect on the tooth, ie any dental manipulation must be performed solely due to the medical indications.

3 . The result of the intervention must meet the following requirements: high aesthetics, sufficient mechanical strength, stable over time and in a humid environment, proper adhesion of the material to the tooth hard tissues.

4. The principle of cooperation between doctor and patient. The patient must participate in the choice of type and shape of the structure, the selection of color and size of the future dental restoration and follow all the recommendations of the doctor, regularly comes for check-ups.

5. The principle of color imitation (due to the optical properties of enamel and dentin with subsequent reproduction of tooth tissues' color). Important conditions in proper color detection - lighting, background and no contrast. It is desirable for doctors to understand the basic laws of optics, physiology and psychology of human visual perception.

6 . The principle of reproduction of tooth hard tissues volume parameters (an appearance of a filling has to correspond to an intact tooth, to repeat its geometrical form, signs of belonging to group of teeth and the part of body). To model the macro-features of the teeth opaque shades of materials must be

19 Руфенахт К.Р. Эстетика в стоматологии. Интегративный подход. М. : МЕДпресс-информ, 2012. 176 с.

${ }^{20}$ Van Dijken J.W., Pallesen U. Posterior bulk-filled resin composite restorations: a 5-year randomized controlled clinical study. J Dent. 2016. Vol. 51. P. 29-35.

${ }^{21}$ Луцкая И.К. Эстетическая стоматология как самостоятельная область стоматологической науки и практики. Соврем. стоматология. 2013. № 1. С. 6-12.

${ }^{22}$ Луцкая И.К., Новак Н.В. Воспроизведение светопроницаемости эмали при эстетическом реставрировании зубов. Стоматолог. 2014. № 2(13). С. 46-51. 
used and to create a microrelief, to form the cutting edge and transparency enamel shades must be used.

7. The principle of adhesive preparation: expanding the area of contact of the filling material with tooth tissues (excision of hard tissues to intact, enamel bevels, cavity shapes). Today, this principle has mostly historical value because modern adhesive systems allow to achieve a high level of adhesion without additional tooth preparation ${ }^{23}$.

8. The principle of minimizing material shrinkage because of photopolymerization which provided for using of special modes of polymerization (this principle is also irrelevant today). In modern photocomposite materials polymerization shrinkage is minimized due to a highly dispersed distribution of photoinitiators of polymerization in the material's volume, as well as when working with modern high-power dental photopolymerizers $^{24,25,26}$.

Additionally, in modern aesthetic dentistry a concept of "pink aesthetics correction" has appeared - visual changes in the shape of the gingival margin which are carried in the following clinical cases:

1) visual correction of the tooth crown length in case of impossibility or refusal of the patient from gingival margin surgical correction;

2) visual removal of gum retraction (including status after periodontal surgery);

3) treatment of root cement caries ${ }^{23}$.

\section{Dental caries approach evolution}

Regarding the evolution of approaches to the treatment of dental caries as the main factor in the appearance of defects in the teeth hard tissues, it still continues in our time. Evidence of this may be considered the pace of implementation of new treatment technologies in practice, new materials for the teeth hard tissues restoration and the emergence of comprehensive treatments, changing opinions about the causes and pathogenesis of caries, its microbiology ${ }^{27}$. And all above mentioned trends occur against the background of special demographic processes in economically developed

${ }^{23}$ Mangani F., Putingano A., Cerutti A. Guidelines for Adhesive Dentistry. The key to success. Quintessence publ., 2009. 418 p.

24 Ломиашвили Л.М., Аюпова Л.Г. Художественное моделирование и реставрация зубов. М. : Медицинская книга, 2004. 434 с.

${ }^{25}$ Ferracane J.L., Hilton T.J. Polymerization stress - Is it clinically meaningful? Dent Mater. 2016. Vol. 32(1). P. 1-10.

${ }^{26}$ Fink J.K. Materials, Chemicals and Methods for Dental Applications. Scrivener Publishing LLC., 2018. 314 p. DOI: 10.1002/9781119510307.

27 Маунт Г. Стоматология минимального вмешательства: современная философия. Дент Арт. 2005. № 1. С. 55-59. 
countries which, generally, sets new tasks for the health care sector and also offers new tools for those task solution in the world (N.P.T. Innes, 2019):

Epidemiology: previously caries was an uncontrolled disease that lead to early tooth loss and affected the entire population; nowadays, we can see mostly the early and uncomplicated cases (mostly among young patients), secondary caries (among adults), uneven distribution in different social groups; in future - tooth roots caries, dental caries combination with periodontal lesions, uneven distribution depending on age.

Etiopathogenesis: previously caries was an infectious disease; nowadays - ecological imbalance (dysbiosis), in future it may be explained as a multi factorial disease.

Diagnostic principles: previously caries was detected by visual and tactile methods; nowadays, we additionally use 2D- and 3D X-ray diagnostics, polarized light and laser diagnostics; in future - all possible diagnostic methods will be applicable.

Treatment strategies: previously dental caries mostly was treated by tooth extraction, extended tooth preparation, amalgam fillings, artificial crowns and dentures; nowadays, in usage we may find fluoride-containing products, adhesive technologies, minimally invasive preparation; for future biomimetic remineralization, modulation of bacterial biofilms and tissue engineering are presented.

Basic approaches: previously dental caries th the all cases mostly was treated with excavation and excision of pathologically altered tissues, restoration of teeth or their removal; nowadays, among current approaches we may find control of biofilms in the oral cavity, remineralization and specialized dental care; for future - regeneration of dental tissues, personal individualized dental care may be presented ${ }^{28}$.

\section{Current technology of dental photocomposite materials}

The progressive advent of composite filling materials in the $60 \mathrm{~s}$ of the XXth century to dental practice forced to change approaches to the tooth tissues preparation for fillings, dental restoration has appeared and become widespread such type of dental works, this also required changes in dental care requirements and quality assessment criteria. The vast majority of publications on this topic in Cyrillic and the recommended protocols for the treatment of teeth hard tissues defects recommend us when choosing a filling

${ }^{28}$ Innes N.P.T., Chu C.H., Fontana M. [et al.]. A Century of Change towards Prevention and Minimal Intervention in Cariology. J Dent Res. 2019. Vol. 98(6). P. 611-617. DOI: 10.1177/0022034519837252. 
material to be guided by the results of the evaluation of its following characteristics ${ }^{29,30}$ :

1. Physical properties: 1) fracture toughness; 2) flexion strength; 3) compression coefficient; 4) resistance to abrasion; 5) elasticity.

2. Polymerization shrinkage.

3. Coefficient of polymerization expansion.

4. Biocompatibility, volumes of residual monomer.

5. Experience of clinical application ${ }^{31,32,33}$.

Modern dental composite materials have some limitations in application, such as: decompensated form of dental caries, dental caries on tooth with unformed roots, certain types of non-carious lesions (special forms of enamel erosion and wedge-shaped defects), poor oral hygiene, frequent recurrences of dental caries. Mostly, such cases are indications for the use of glass ionomer cements, compomers and hyomers. Despite this, today the best material for practical dentistry is considered to be light-cured composite filling materials ${ }^{34,35}$.

According to the definition of "dental composite" proposed by R.W. Philips, composite filling material is "a three-dimensional combination of at least two different in composition and chemical structure of materials with a clear distribution boundary". Such a combination of components has more advantageous physical, chemical, biological and working qualities than each component separately. The first composite filling dental materials appeared in the United States of America in the late 50's of XX century. The

${ }^{29}$ Модринская Ю.В., Храмченко С.Н. Методы минимально инвазивного лечения кариеса зубов. ART-метод. Туннельная реставрация : учеб.-метод. пособие. БГМУ, $2010.31 \mathrm{c}$.

30 Храмченко С.Н. Отдаленные результаты минимально инвазивного лечения кариеса боковых зубов с применением адгезивных систем разных классов. Стоматологический журнал. 2008. № 2. С. 127-131.

${ }^{31}$ Gonçalves F., Campos L.M.P., Rodrigues-Júnior E.C. [et al.]. A comparative study of bulk-fill composites: Degree of conversion, post-gel shrinkage and cytotoxicity. Braz. Oral Res. 2018. Vol. 32. P. 17-25. DOI: 10.1590/1807-3107bor-2018.vol32.0017.

${ }^{32}$ Kuper N. Secondary caries, Mind the gap: Diss. PhD / Radboud University. Nijmegen, 2019. $125 \mathrm{p}$.

${ }^{33}$ Hamlin N.J., Bailey C., Motyka N.C., Vandewalle K.S. Effect of tooth-structure thickness on light attenuation and depth of cure. Oper Dent. 2016. Vol. 41(2). P. 200-207. DOI: 10.2341/15-067-L.

${ }^{34}$ Lima I.P.C., Medeiros F. da C.D. de, Santos M.M. Clinical evaluation of two materials in the restoration of abfraction lesions Clinical evaluation of two materials in the restoration of abfraction lesions. Brazilian Journal of Oral Sciences. 2015. Vol. 14(4). P. 287-293.

35 Maas M.S., Alania Y., Natale L.C. [et al.]. Trends in restorative composites research: What is in the future? Braz. Oral Res. 2017. Vol. 31. P. 55-60. DOI: 10.1590/1807-3107BOR-2017.vol31.0055. 
emergence of such technology is associated with a historical figure in Dentistry - Dr. Ray L. Bowen. The first materials of new era on the dental market were composite materials with a chemical curing mechanism, created by 3 M-corporation in $1964^{36,14,13,37}$.

The appearance of such materials in clinical practice significantly improved the aesthetic results of dental treatment (because the main and widespread filling material at that time was silver amalgam). Chemical curing composites were produced in the form of two pastes (basic and catalytic) which solidified after mixing. However, the first composite materials had a wide range of disadvantages - uneven and irregular configuration of filler particles, low dispersion of their location in the mass, such material was quite brittle, worn quickly, had low color stability and adhesion to tooth hard tissue was insufficient to ${ }^{38,39}$.

Also, practitioners faced a number of complications after the use of the first dental composites of chemical curing - recidives of caries, toxic pulpits, postoperative hypersensitivity of the teeth. Therefore, the indications for the use of such materials were significantly narrowed but the technology of dental composites has developed further. Gradually, composite materials improved - they became more durable, obtained color stability, improved physical and mechanical properties and changed the method of polymerization.

In the early 1980s there were two areas of improvement in composite technology: composites for the restoration of frontal teeth (more aesthetic) and composites for the restoration of the masticatory group of teeth where the main criterion of quality is the strength and durability of the material. Subsequently, 10 years later, universal filling (restorative) materials appeared, they combined the properties of materials for filling both groups frontal and masticatory teeth, i.e. had both aesthetics and sufficient strength. But in the late XXth century most of composite manufacturers and dentists came to the consensus that filling material should not be universal but should be selected according to every clinical situation ${ }^{9,25,14}$.

36 Данилевский Н.Ф., Борисенко А.В., Политун А.М. Терапевтическая стоматология : учебник; в 4 т. Т. 1. Фантомный курс / под ред. А.В. Борисенко. К. : Медицина, 2009. 400 c.

${ }^{37}$ Anusavice K.J., Shen C., Rawls H.R. Phillips' science of dental materials. Elsevier Health Sciences, 2012. 592 p.

38 Nyheter S. Amalgam and mercury banned. 2014. URL: http://www.svd.se/nyheter/inrikes/amalgam-ochkvicksilver-forbjuds_724369.svd.

${ }^{39}$ Opdam N.J.M., van de Sande F.H., Bronkhorst E. [et al.]. Longevity of posterior composite restorations: a systematic review and meta-analysis. J. Dent. Res. 2014. Vol. 93. P. 943-949. DOI: 10.1177/0022034514544217. 
Today, dental care is the most commercialized branch of practical health care service in Ukraine and in most cases the processes that take place in dental care are determined by the laws of the market and the economy. It is worth noting the trend in dental care in the post-Soviet space to perform the direct composite dental restorations which tend to be explained by economic reasons. On the other hand, we can see a trend bordering on polypragmatism when there is a maximum expansion of indications for direct composite restorations which does not coincide with the generally accepted principles of biological and clinical feasibility of dental treatment.

Therefore, today in scientific periodicals and other sources of scientific and medical information you can find long and intense discussions about the advantages and disadvantages of direct and indirect methods of tooth restoration. Among the arguments in favor of one method or another can often be found emphasis on the solvency of the patient, his social and cultural level. The authors also tend to emphasize the market orientation of dental care ${ }^{1}$.

Regarding the properties and qualities of modern composite dental filling materials, they are determined by the peculiarities of their chemical composition and spatial organization. In the composition of each composite dental material we can find 3 parts (phases):

1. Polymer matrix (organic matrix). Today, the organic matrix of most dental composites is the product of the interaction of acrylic and epoxy resins - Bis-GMA. Bis-GMA is a copolymer of bisphenol and glycidyl methacrylate, such a compound in the monomer has a high molecular weight. Isolated Bis-GMA has a high viscosity $(\eta=1200 \mathrm{~Pa} \cdot \mathrm{s})$. So to avoid this problem in the matrix composition add other resins with reduced viscosity triethylene glycol-dimethyl methacrylate (TegDMA, $\eta=0,006 \mathrm{~Pa} \cdot \mathrm{s})$ and a monomer with low molecular weight - urethane dimethyl methacrylate (UDMA), decanedioldimethyl methacrylate (D3MA).

These compositions are able to improve the operational properties of the matrix and, accordingly, the composite material itself. Further, in order to eliminate the negative phenomenon of "polymerization stress" applications in the form of silorane and thiolene systems were proposed ${ }^{40}$. The composition of the organic matrix of composite materials also includes the following components: 1) polymerization inhibitors (prevent spontaneous polymerization, extend the working time of the material and increase its service life); 2) catalysts and activators - initiate the start of polymerization, as well as accelerate the rate of polymerization (benzoyl peroxide, camphoraquinone and quaternary amines); 3) ultraviolet absorbers, which

${ }^{40}$ Pala K., Tekçe N., Tuncer S. [et al.]. Flexural strength and microhardness of anterior composites after accelerated aging. J. Clin. Exp. Dent. 2017. Vol. 9. P. 424-430. DOI: $10.4317 /$ jced.53463. 
increase the color stability of composites, especially when exposed to sunlight; 4) pigments that determine the color and shade of the material.

2. Filler (dispersed phase). The inclusion of an inorganic filler determines the mechanical properties and structural stability of the polymerized composite, and also provides the following advantages: 1) reduction of polymerization shrinkage to $0,70 \%$; 2 ) prevention of changes in the organic matrix; 3) reduction of water absorption; 4) reduction of abrasion of the material; 5) increase in resistance to loads; 6) strengthening of mechanical strength; 7) improvement of aesthetic properties.

In modern dental composite materials a modified glass and possible inclusions of other compounds (such as zirconium oxide, etc.) are used as a solid-phase filler. Also, each manufacturer has own technology of grinding and dispersing the filler of composites, quite often manufacturers perform hybridization of particles of different sizes. The particle size of the inorganic filler is fixed in the range from 45,00 to $0,04 \mu \mathrm{m}$. The first composite materials had large filler particles - more than 10,00 $\mu \mathrm{m}$. Modern manufacturers have gone by reducing the average particle size. A whole set of materials is used as a filler: fused and crystalline quartz, aluminosilicate glass, borosilicate and barium glass, diamond dust, various variants of silicon dioxide. Also shape of the filler particles may be different - ground, crumbly, spherical, in the form of sticks and shavings ${ }^{9,25,14}$.

3. A necessary component of modern dental composite materials are surfactants - silanes which provide a bipolar bonding between the inorganic filler and the organic polymer matrix. The vast majority of silanes used in dentistry are bifunctional molecules - one side of them may contain one or more reactive groups (methacrylate, acrylate, epoxy, etc.) to form a bonding with the organic matrix, while the other side is capable of form bonding with the filler. Silanes contribute to the emergence of stable and strong interactions between the components of the dental composite. Such bonds are crucial in the composite's acquisition of stability and mechanical hardness. In the absence of these bonds or in their weak interactions water and various substances easily get into the space between the matrix and the filler which leads to the loss of filler particles from the composite ${ }^{41}$.

\section{Future of composite dental resins}

Thus, based on the analysis of publications we can summarize that aesthetic and cosmetic interventions on teeth today are an active direction in the development of dental care with broad clinical indications where more

${ }^{41}$ Gupta L., Aparna I.N., Bhat S., Ginjupalli K. Effect of comonomer of methacrylic acid on flexural strength and adhesion of Staphylococcus aureus to heat polymerized poly (methyl methacrylate) resin: An in vitro study. J Indian Prosthodont Soc. 2017. Vol. 17(2). P. 149-155. DOI: 10.4103/jips.jips_257_16. 
and more innovative technologies are being fully implemented. That process became possible after the appearance in dental practice of new materials, in particular - composites, which combine balanced optical, mechanical and physical properties, as well as are biocompatible. Today, the technology of dental composite filling materials continues to improve and scientific research is performed in the following strategic areas ${ }^{42,43}$ :

1. Improvement of components (development of new types of organic resins and fillers $)^{44,45}$.

2. Studying of composite polymerization processes ${ }^{46,47}$.

3. Creation of new highly dispersed composite materials ${ }^{48,49}$.

4. Creation of composite materials with anti-carious and bioactive properties $^{50,51}$.

${ }^{42}$ Akalin T., Genc G., Korkmaz Ceyhan Y., Ozturk Bozkur F. The effect of mouth rinses on the color stability of sonicfill and a nanohybrid composite. J Instanb Univ Fac Dent. 2016. Vol. 50. P. 17-23. DOI: 10.17096/jiufd.15743.

${ }^{43}$ Berge T.L.L., Lygre G.B., Lie S.A., Björkman L. Polymer-based dental filling materials placed during pregnancy and risk to the foetus. BMC Oral Health. 2018. Vol. 22. № 18(1). P. 144. DOI: 10.1186/s12903-018-0608-1.

${ }^{44}$ Aydınoğlu A., Yoruç A.B.H. Effects of silane-modified fillers on properties of dental composite resin. Mater. Sci. Eng. C. 2017. Vol. 79. P. 382-389. DOI: 10.1016/j.msec.2017.04.151.

${ }^{45}$ Bacchi A., Pfeifer C.S. Rheological and mechanical properties and interfacial stress development of composite cements modified with thio-urethane oligomers. Dent Mater. 2016. Vol. 32(8). P. 978-986. DOI: 10.1016/j.dental.2016.05.003.

${ }^{46}$ Agarwal P.M., Taneja S., Kumar M. To evaluate and compare the effect of different light-curing modes and different liners on cuspal deflection in premolar teeth restored with bulk filled or incrementally filled composite measured at different time intervals. J Conserv Dent. 2017. Vol. 20. P. 317-321. DOI: 10.4103/JCD.JCD_328_16.

47 Al-Shaafi M.M. Factors affecting polymerization of resin-based composites: A literature review. Saudi Dent. J. 2017. Vol. 29. P. 48-58. DOI: 10.1016/j.sdentj. 2017.01.002.

${ }^{48}$ De Oliveira D.C.R.S., de Menezes L.R., Gatti A. [et al.]. Effect of Nanofiller Loading on Cure Efficiency and Potential Color Change of Model Composites. J. Esthet. Restor. Dent. 2016. Vol. 28. P. 171-177. doi: 10.1111/jerd.12189.

${ }^{49}$ Łukomska-Szymańska M.M., Kleczewska J., Bieliński D.M. [et al.]. Bactericidal properties of experimental dental composites based on dimethacrylate resins reinforced by nanoparticles. Eur. J. Chem. 2014. Vol. 5. P. 419-423. DOI: 10.5155/eurjchem.5.3.419423.1019.

${ }^{50}$ Melo M.A., Cheng L., Zhang K. [et al.]. Combating dental caries via restorative materials containing antibacterial and remineralizing nanoparticles. Technical Proceedings of the 2014 NSTI Nanotechnology Conference and Expo, NSTI-Nanotech 2014. Nanotech. 2014. Vol. 2. P. 289-292.

${ }^{51}$ Liang K., Weir M.D., Xie X. [et al.]. Dentin remineralization in acid challenge environment via PAMAM and calcium phosphate composite. Dent Mater. 2016. Vol. 32(11). P. 1429-1440. DOI: 10.1016/j.dental.2016.09.013. 
5. Improving the technique of adhesion of the composite to the tooth hard tissues $^{52,53}$.

6. Creation of dental composites capable to self-heal after mechanical damage ${ }^{54,55}$.

7. Investigation of the properties of cariogenic microorganisms of the oral cavity and leveling the pathogenic action of strains capable of dissolving polymerized composite materials ${ }^{56,57}$.

8. Improvement and implementation in practice the dental composites for "bulk-restorations"

9. Creation of new hybrid materials ${ }^{60,61}$.

10. Evaluation of the results of the usage of composite filling materials in clinical practice ${ }^{62,63,64}$.

52 Rodrigues N.S., de Souza L.C., Feitosa V.P. [et al.]. Effect of different conditioning/deproteinization protocols on the bond strength and degree of conversion of self-adhesive resin cements applied to dentin. Int. J. Adhes. Adhes. 2017. DOI: 10.1016/j.ijadhadh.2017.03.013.

${ }^{53}$ Shafiei F., Saadat M. Micromorphology and bond strength evaluation of adhesive interface of a self-adhering flowable composite resin-dentin: effect of surface treatment. Microsc Res Tech. 2016. Vol. 79(5). P. 403-407. DOI: 10.1002/jemt.22643.

${ }^{54}$ Wu J., Weir M.D., Melo M.A.S. [et al.]. Effects of water-aging on self-healing dental composite containing microcapsules. J Dent. 2016. Vol. 47. P. 86-93. DOI: 10.1016/j.jdent.2016.01.008.

${ }^{55}$ Huyang G., Debertin A.E., Sun J. Design and development of self-healing dental composites. Mater Des. 2016. Vol. 94. P. 295-302. Doi: 10.1016/j.matdes.2016.01.046.

${ }^{56}$ Wang J., Dong X., Yu Q. [et al.]. Incorporation of antibacterial agent derived deep eutectic solvent into an active dental composite. Dent. Mater. Off. Publ. Acad. Dent. Mater. 2017. Vol. 33. P. 1445-1455. DOI: 10.3390/molecules25204738.

57 Rego G.F., Vidal M.L., Viana G.M. [et al.]. Antibiofilm properties of model composites containing quaternary ammonium methacrylates after surface texture modification. Dent. Mater. Off. Publ. Acad. Dent. Mater. 2017. Vol. 33. P. 1149-1156. DOI: 10.1016/j.dental.2017.07.010.

58 Maghaireh G.A., Price R.B., Abdo N. [et al.]. Effect of thickness on light transmission and vickers hardness of five bulk-fill resin-based composites using polywave and single-peak light-emitting diode curing lights. Oper Dent. 2018.Vol. 6. P. 17-163. DOI: 10.2341/17-163-L.

${ }^{59}$ Van Ende A., Lise D.P., De Munck J. [et al.]. Strain development in bulk-filled cavities of different depths characterized using a non-destructive acoustic emission approach. Dent Mater. 2017. Vol. 33(4). P. 165-177. DOI: 10.1016/j.dental.2016.12. 012.

${ }^{60}$ Melo M.A., Orrego S., Weir M.D. [et al.]. Designing Multiagent Dental Materials for Enhanced Resistance to Biofilm Damage at the Bonded Interface. ACS Appl. Mater. Interfaces. 2016. Vol. 8. P. 11779-11787. DOI: 10.1021/acsami.6b01923.

${ }^{61}$ Bollu I.P., Hari A., Thumu J. [et al.]. Comparative Evaluation of Microleakage Between Nano-Ionomer, Giomer and Resin Modified Glass Ionomer Cement in Class V Cavities - CLSM Study. J Clin Diagn Res. 2016. Vol. 10(5). P. 66-70. DOI: $10.7860 / J C D R / 2016 / 18730.7798$. 


\section{Special conditions of domestic dental composites manufacturing in Ukraine}

Today in Ukraine the reform of the legislation regulating the issues of biological and ecological safety of dental materials and all medical devices in general is underway. Generally, there is an approximation of national legislation of Ukraine to international standards and norms of European and law.

In modern conditions, the processes of production, testing and certification, as well as post-marketing supervision are regulated by the following regulations of Ukraine: the laws of Ukraine "On Standardization" (from 05.06.2014 № 1315-VII), "On technical regulations and conformity assessment" (from 15.01.2015 № 124-VIII), Resolution of the Cabinet of Ministers of Ukraine № 753 from 02.10.2013 “On approval of technical regulations on medical devices", Law of Ukraine "On the permit system in the sphere of economic activity" (from 06.09.2005 06 2806-IV), "On Medicinal Products” (dated 04.04.1996 № 123/96-VR), “On General Safety of Non-Food Products" (02.12.2010 № 2736-VI), “On State market supervision and control of non-food products" (from 02.12.2010 № 2735-VI), "On the basic principles of state supervision (control) in the sphere of economic activity" (from 05.04.2007 № 877-V), Order of the Ministry of Health of Ukraine from 11.10.2017 № 1245 "On approval of the list of national standards, compliance with which provides the presumption of conformity of medical devices with the requirements of the Technical Regulation on Medical Devices", European Council Directive of 14 June 1993 № 93/42/EEC on medical devices, Regulations of the European Parliament and of the Council 2017/745 "On medical devices" and 2017/746 medical devices for in vitro diagnostics".

DSTU EN 1641: 2015 Dentistry. Medical equipment for dentistry. Raw materials, DSTU EN 1642: 2015 Dentistry. Medical equipment for dentistry. Dental implants. In general, the current Law of Ukraine "On Technical Regulations and Conformity Assessment" provides for the gradual implementation in national legislation and by-laws of the Regulations of the

${ }^{62}$ Vieira A.R., Silva M.B., Souza K.K.A. [et al.]. A Pragmatic Study Shows Failure of Dental Composite Fillings Is Genetically Determined: A Contribution to the Discussion on Dental Amalgams. Front Med (Lausanne). 2017. Vol. 6(4). P. 186. DOI: $10.3389 / \mathrm{fmed} .2017 .00186$.

${ }^{63}$ Pereira R., Giorgi M.C.C., Lins R.B.E. [et al.]. Physical and photoelastic properties of bulk-fill and conventional composites. Clin Cosmet Investig Dent. 2018. Vol. 10. P. 287-296. DOI: 10.2147/CCIDE.S184660.

${ }^{64}$ Da Rosa G.M., da Silva L.M., de Menezes M. [et al.]. Effect of whitening dentifrices on the surface roughness of a nanohybrid composite resin. Eur J Dent. 2016. Vol. 10(2). P. 170-175. DOI: 10.4103/1305-7456.178305. 
European Parliament and of the European Council № 93/42/EEC, 2017/745 "On medical devices" and 2017/746 "On medical devices. Products for in vitro diagnostics" dated April 5, $2017^{65,66,67}$.

\section{CONCLUSIONS}

Nowadays, dental photocomposites are the most widespread dental materials in the world. Due to the high incidence of dental caries in Ukraine a great part of the population has need in affected teeth treatment by restoration of crowns with different methods and materials. Modern dental photocomposites - a progressive and high-technological products which may take a strategically important place in supplying of dentistry (as a part of public health). Improvements and modifications of dental photocomposite restorative materials are permanently performing. Ukraine, as a country with presented domestic manufacturing of composites shows good perspectives for its enhancing and introduction of import-replacing elements. Improvement and modifications of dental composites may provide the additional benefits for population and also for state function.

Today in Ukraine the reform of the legislation regulating the issues of biological and ecological safety of dental materials and all medical devices in general is underway. Generally, there is an approximation of national legislation of Ukraine to international standards and norms of European and law.

\section{SUMMARY}

Nowadays, a treatment of dental caries with the next installation of fillings using composite restorative materials is the most common type of dental medical care in the world. Modern dental light-cured composite filling materials hold a leading place among all restorative materials in dentistry, as to their aesthetic, mechanical and technological properties. But practical dentistry still has needs to create an "ideal" composite dental filling material.

The modern ways of improvement of dental composite are visualizing in the next directions: improvement of components (development of new types of organic resins and fillers). Also, studying of polymerization processes, creation of new highly dispersed materials with anti-carious and bioactive

65 Мочалов Ю.О. Дослідження безпечності стоматологічних пломбувальних матеріалів відповідно до вимог групи стандартів ISO 10993 (огляд літератури). Молодий вчений. 2018. № 6(58). С. 269-272.

${ }^{66}$ Мочалов Ю.О. Комплексне обгрунтування вдосконалення лікування зубів із дефектами твердих тканин в умовах розвитку імпортозаміщення пломбувальних матеріалів. Дис. д-ра мед.н. Ужгород : УжНУ, 2020. 434 с.

67 Патіота Л.Е., Харченко Т.Ф., Левицька В.М. [та ін.]. Основи технічного регулювання медичних виробів. Сучасні проблеми токсикологї, харчової та хімічної безпеки. 2015. № 3. С. 104-106. 
properties; improving the technique of adhesion to the tooth hard tissues; self-healing materials. Also, investigation of cariogenic microorganism's influence on polymerised composite materials, improvement of "bulk" dental composites; creation of new hybrid materials; evaluation of the results of the usage in clinical practice.

\section{REFERENCES}

1. Мочалов Ю.О. Комплексне обгрунтування вдосконалення лікування зубів із дефектами твердих тканин в умовах розвитку імпортозаміщення пломбувальних матеріалів. Дис. д-ра мед.н. Ужгород : УжНУ, 2020. $434 \mathrm{c}$.

2. Клітинська О.В., Мочалов Ю.О., Дячук К.Г. [та ін.]. Особливості поширення карієсу зубів у школярів старших класів міста Ужгород. Молодий вчений. 2015. № 10(2). С. 170-172.

3. Дорошенко О.О. Сучасний стан фінансово-економічного забезпечення медичної допомоги на вторинному рівні. Державне управління: удосконалення та розвиток. 2017. № 2. URL: http://www.dy.nayka.com.ua/?op=1\&z=1038.

4. Мазур І.П. Про стан і перспективи стоматологічної допомоги в Україні. Современная стоматология. 2017. № 2. С. 69-71.

5. Кононова О.В. Сучасний стан лікування карієсу та його ускладнень у населення України. Гігієна населених місиь. 2014. № 64. C. $336-342$.

6. Любченко О.В. Оценка экономической эффективности применения отечественных материалов при лечении осложненного кариеса в сравнении с импортными аналогами. Вісник проблем біології $i$ медицини. 2015. № 2(1). С. 344-347.

7. Ai M., Du Z., Zhu S. [et al.]. Composite resin reinforced with silver nanoparticles-laden hydroxyapatite nanowires for dental application. Dent. Mater. Off. Publ. Acad. Dent. Mater. 2017. Vol. 33. P. 12-22. DOI: 10.1016/j.dental.2016.09.038.

8. Al-Sunbul H., Silikas N., Watts D.C. Polymerization shrinkage kinetics and shrinkage-stress in dental resin-composites. Dent Mater. 2016. Vol. 32(8). P. 998-1006. DOI: 10.1016/j.dental.2016.05.006.

9. Удод О.А., Борисенко О.М. Лабораторне дослідження крайового прилягання нанофотокомпозиційного матеріалу. Вісник проблем біології і медицини. 2019. № 1(1). С. 244-247.

10. Храмченко С.Н., Казеко Л.А. Композитные материалы в терапевтической стоматологии : учебно-методическое пособие. Минск : БГМУ, 2007. 20 с.

11. Ástvaldsdóttir Á., Dagerhamn J., van Dijken J.W.V. [et al.]. Longevity of posterior resin composite restorations in adults - A systematic 
review. J. Dent. 2015. Vol. 43. P. 934-954. DOI: 10.1016/j.jdent.2015.05.001.

12. Kidd E., Fejerskov O. Changing concepts in cariology: forty years on. Dent Update. 2013. Vol. 40, № 4. P. 277-286. 10.12968/denu.2013.40.4.277.

13. Kim E.H., Jung K.H., Son S.A. [et al.]. Effect of resin thickness on the microhardness and optical properties of bulk-fill resin composites. Restor Dent Endod. 2015. Vol. 40(2). P. 128-135. DOI: 10.5395/rde.2015.40.2.128.

14. Николаев А.И., Цепов Л.М. Практическая терапевтическая стоматология : учеб. пособие. М. : МЕДпресс-информ, 2014. 928 с.

15. Курсевич К.Е. Факторы, влияющие на цветостабильность пломбировочных материалов : вып. кв. раб. Санкт-Петербург, 2018. 53 с.

16. Ніколішин А.К. Терапевтична стоматологія : підручник для студентів стоматологічного факультету вищих медичних навчальних закладів IV рівня акредитації. Вінниця : Нова Книга, 2012. 680 с.

17. Алексеева Е.Г., Кравцов Р.В. Использование суперопаковых оттенков композитного материала "Jen-Radiance" для реализации минимально инвазивной эстетической реставрации зубов фронтального участка. Современная стоматология. 2016. № 2. С. 20-22.

18.Безвушко Е.В., Шпотюк О.О. Оцінка застосування пломбувальних матеріалів для відновлення твердих тканин постійних зубів у дітей. Вісник Української медичної стоматологічної академії. 2017. Т. 17, Вип. 3. С. 191-194.

19. Руфенахт К.Р. Эстетика в стоматологии. Интегративный подход. М. : МЕДпресс-информ, 2012. 176 с.

20. Van Dijken J.W., Pallesen U. Posterior bulk-filled resin composite restorations: a 5-year randomized controlled clinical study. J Dent. 2016. Vol. 51. P. 29-35.

21. Луцкая И.К. Эстетическая стоматология как самостоятельная область стоматологической науки и практики. Соврем. стоматология. 2013. № 1. С. 6-12.

22. Луцкая И.К., Новак Н.В. Воспроизведение светопроницаемости эмали при эстетическом реставрировании зубов. Стоматолог. 2014. № 2(13). C. 46-51.

23. Mangani F., Putingano A., Cerutti A. Guidelines for Adhesive Dentistry. The key to success. Quintessence publ., 2009. 418 p.

24. Ломиашвили Л.М., Аюпова Л.Г. Художественное моделирование и реставрация зубов. М. : Медицинская книга, 2004. 434 с.

25. Ferracane J.L., Hilton T.J. Polymerization stress - Is it clinically meaningful? Dent Mater. 2016. Vol. 32(1). P. 1-10.

26. Fink J.K. Materials, Chemicals and Methods for Dental Applications. Scrivener Publishing LLC., 2018. 314 p. DOI:10.1002/9781119510307. 
27. Маунт $\quad$ Г. Стоматология минимального вмешательства: современная философия. Дент Арт. 2005. № 1. С. 55-59.

28. Innes N.P.T., Chu C.H., Fontana M. [et al.]. A Century of Change towards Prevention and Minimal Intervention in Cariology. J Dent Res. 2019. Vol. 98(6). P. 611-617. DOI: 10.1177/0022034519837252.

29. Модринская Ю.В., Храмченко С.Н. Методы минимально инвазивного лечения кариеса зубов. ART-метод. Туннельная реставрация : учеб.-метод. пособие. БГМУ, 2010. 31 с.

30. Храмченко С.Н. Отдаленные результаты минимально инвазивного лечения кариеса боковых зубов с применением адгезивных систем разных классов. Стоматологический журнал. 2008. № 2. C. 127-131.

31. Gonçalves F., Campos L.M.P., Rodrigues-Júnior E.C. [et al.]. A comparative study of bulk-fill composites. Degree of conversion, post-gel shrinkage and cytotoxicity. Braz. Oral Res. 2018. Vol. 32. P. 17-25. DOI: 10.1590/1807-3107bor-2018.vol32.0017.

32. Kuper N. Secondary caries, Mind the gap: Diss. PhD / Radboud University. Nijmegen, 2019. $125 \mathrm{p}$.

33. Hamlin N.J., Bailey C., Motyka N.C., Vandewalle K.S. Effect of tooth-structure thickness on light attenuation and depth of cure. Oper Dent. 2016. Vol. 41(2). P. 200-207. DOI: 10.2341/15-067-L.

34. Lima I.P.C., Medeiros F. da C.D. de, Santos M.M. Clinical evaluation of two materials in the restoration of abfraction lesions Clinical evaluation of two materials in the restoration of abfraction lesions. Brazilian Journal of Oral Sciences. 2015. Vol. 14(4). P. 287-293.

35. Maas M.S., Alania Y., Natale L.C. [et al.]. Trends in restorative composites research: What is in the future? Braz. Oral Res. 2017. Vol. 31. P. 55-60. DOI: 10.1590/1807-3107BOR-2017.vol31.0055.

36. Данилевский Н.Ф., Борисенко А.В., Политун А.M. Терапевтическая стоматология : учебник; в 4 т. Т. 1. Фантомный курс / под ред. А.В. Борисенко. К. : Медицина, 2009. 400 с.

37. Anusavice K.J., Shen C., Rawls H.R. Phillips' science of dental materials. Elsevier Health Sciences, 2012. 592 p.

38. Nyheter S. Amalgam and mercury banned. 2014. URL: http://www.svd.se/nyheter/inrikes/amalgam-ochkvicksilverforbjuds_724369.svd.

39. Opdam N.J.M., van de Sande F.H., Bronkhorst E. [et al.]. Longevity of posterior composite restorations: a systematic review and meta-analysis. J. Dent. Res. 2014. Vol. 93. P. 943-949. DOI: 10.1177/0022034514544217.

40. Pala K., Tekçe N., Tuncer S. [et al.]. Flexural strength and microhardness of anterior composites after accelerated aging. J. Clin. Exp. Dent. 2017. Vol. 9. P. 424-430. DOI: 10.4317/jced.53463. 
41. Gupta L., Aparna I.N., Bhat S., Ginjupalli K. Effect of comonomer of methacrylic acid on flexural strength and adhesion of Staphylococcus aureus to heat polymerized poly (methyl methacrylate) resin: An in vitro study. J Indian Prosthodont Soc. 2017. Vol. 17(2). P. 149-155. doi: 10.4103/jips.jips_257_16.

42. Akalin T., Genc G., Korkmaz Ceyhan Y., Ozturk Bozkur F. The effect of mouth rinses on the color stability of sonicfill and a nanohybrid composite. J Instanb Univ Fac Dent. 2016. Vol. 50. P. 17-23. DOI: 10.17096/jiufd.15743.

43. Berge T.L.L., Lygre G.B., Lie S.A., Björkman L. Polymer-based dental filling materials placed during pregnancy and risk to the foetus. $B M C$ Oral Health. 2018. Vol. 22. № 18(1). P. 144. doi: 10.1186/s12903-0180608-1.

44. Aydınoğlu A., Yoruç A.B.H. Effects of silane-modified fillers on properties of dental composite resin. Mater. Sci. Eng. C. 2017. Vol. 79. P. 382-389. doi: 10.1016/j.msec.2017.04.151.

45. Bacchi A., Pfeifer C.S. Rheological and mechanical properties and interfacial stress development of composite cements modified with thiourethane oligomers. Dent Mater. 2016. Vol. 32(8). P. 978-986. DOI: 10.1016/j.dental.2016.05.003.

46. Agarwal P.M., Taneja S., Kumar M. To evaluate and compare the effect of different light-curing modes and different liners on cuspal deflection in premolar teeth restored with bulk filled or incrementally filled composite measured at different time intervals. J Conserv Dent. 2017. Vol. 20. P. 317-321. DOI: 10.4103/JCD.JCD_328_16.

47. Al-Shaafi M.M. Factors affecting polymerization of resin-based composites: a literature review. Saudi Dent. J. 2017. Vol. 29. P. 48-58. DOI: 10.1016/j.sdentj. 2017.01.002.

48. De Oliveira D.C.R.S., de Menezes L.R., Gatti A. [et al.]. Effect of Nanofiller Loading on Cure Efficiency and Potential Color Change of Model Composites. J. Esthet. Restor. Dent. 2016. Vol. 28. P. 171-177. DOI: $10.1111 /$ jerd.12189.

49. Łukomska-Szymańska M.M., Kleczewska J., Bieliński D.M. [et al.]. Bactericidal properties of experimental dental composites based on dimethacrylate resins reinforced by nanoparticles. Eur. J. Chem. 2014. Vol. 5. P. 419-423. DOI: 10.5155/eurjchem.5.3.419-423.1019.

50. Melo M.A., Cheng L., Zhang K. [et al.]. Combating dental caries via restorative materials containing antibacterial and remineralizing nanoparticles. Technical Proceedings of the 2014 NSTI Nanotechnology Conference and Expo, NSTI-Nanotech 2014. Nanotech. 2014. Vol. 2. P. 289-292. 
51. Liang K., Weir M.D., Xie X. [et al.]. Dentin remineralization in acid challenge environment via PAMAM and calcium phosphate composite. Dent Mater. 2016. Vol. 32(11). P. 1429-1440. DOI: 10.1016/j.dental.2016.09.013.

52. Rodrigues N.S., de Souza L.C., Feitosa V.P. [et al.]. Effect of different conditioning / deproteinization protocols on the bond strength and degree of conversion of self-adhesive resin cements applied to dentin. Int. J. Adhes. Adhes. 2017. doi: 10.1016/j.ijadhadh.2017.03.013.

53. Shafiei F., Saadat M. Micromorphology and bond strength evaluation of adhesive interface of a self-adhering flowable composite resin-dentin: effect of surface treatment. Microsc Res Tech. 2016. Vol. 79(5). P. 403-407. DOI: $10.1002 /$ jemt.22643.

54. Wu J., Weir M.D., Melo M.A.S. [et al.]. Effects of water-aging on self-healing dental composite containing microcapsules. J Dent. 2016. Vol. 47. P. 86-93. DOI: 10.1016/j.jdent.2016.01.008.

55. Huyang G., Debertin A.E., Sun J. Design and development of selfhealing dental composites. Mater Des. 2016. Vol. 94. P. 295-302. DOI: 10.1016/j.matdes.2016.01.046.

56. Wang J., Dong X., Yu Q. [et al.]. Incorporation of antibacterial agent derived deep eutectic solvent into an active dental composite. Dent. Mater. Off. Publ. Acad. Dent. Mater. 2017. Vol. 33. P. 1445-1455. DOI: $10.3390 /$ molecules25204738.

57. Rego G.F., Vidal M.L., Viana G.M. [et al.]. Antibiofilm properties of model composites containing quaternary ammonium methacrylates after surface texture modification. Dent. Mater. Off. Publ. Acad. Dent. Mater. 2017. Vol. 33. P. 1149-1156. DOI: 10.1016/j.dental.2017.07.010.

58. Maghaireh G.A., Price R.B., Abdo N. [et al.]. Effect of thickness on light transmission and vickers hardness of five bulk-fill resin-based composites using polywave and single-peak light-emitting diode curing lights. Oper Dent. 2018. Vol. 6. P. 17-163-L. doi: 10.2341/17-163-L.

59. Van Ende A., Lise D.P., De Munck J. [et al.]. Strain development in bulk-filled cavities of different depths characterized using a non-destructive acoustic emission approach. Dent Mater. 2017. Vol. 33(4). P. 165-177. DOI: 10.1016/j.dental.2016.12. 012.

60. Melo M.A., Orrego S., Weir M.D. [et al.]. Designing Multiagent Dental Materials for Enhanced Resistance to Biofilm Damage at the Bonded Interface. ACS Appl. Mater. Interfaces. 2016. Vol. 8. P. 11779-11787. DOI: 10.1021/acsami.6b01923.

61. Bollu I.P., Hari A., Thumu J. [et al.]. Comparative Evaluation of Microleakage Between Nano-Ionomer, Giomer and Resin Modified Glass Ionomer Cement in Class V Cavities-CLSM Study. J Clin Diagn Res. 2016. Vol. 10(5). P. 66-70. DOI: 10.7860/JCDR/2016/18730.7798. 
62. Vieira A.R., Silva M.B., Souza K.K.A. [et al.]. A Pragmatic Study Shows Failure of Dental Composite Fillings Is Genetically Determined: a Contribution to the Discussion on Dental Amalgams. Front Med (Lausanne). 2017. Vol. 6(4). P. 186. doi: 10.3389/fmed.2017.00186.

63. Pereira R., Giorgi M.C.C., Lins R.B.E. [et al.]. Physical and photoelastic properties of bulk-fill and conventional composites. Clin Cosmet Investig Dent. 2018. Vol. 10. P. 287-296. DOI: 10.2147/CCIDE.S184660.

64. Da Rosa G.M., da Silva L.M., de Menezes M. [et al.]. Effect of whitening dentifrices on the surface roughness of a nanohybrid composite resin. Eur J Dent. 2016. Vol. 10(2). P. 170-175. DOI: 10.4103/ 1305-7456.178305.

65. Мочалов Ю.О. Дослідження безпечності стоматологічних пломбувальних матеріалів відповідно до вимог групи стандартів ISO 10993 (огляд літератури). Молодий вчений. 2018. № 6(58). C. $269-272$.

66. Патіота Л.Е., Харченко Т.Ф., Левицька В.М. [та ін.]. Основи технічного регулювання медичних виробів. Сучасні проблеми токсикології, харчової та хімічної безпеки. 2015. № 3. С. 104-106.

\section{Information about the authors: Mochalov Yu. O., orcid.org/0000-0002-5654-1725}

Doctor of Medical Sciences, Associated Professor, Associated Professor at the Department of Surgical Dentistry, Maxillofacial Surgery and Onco-Dentistry Uzhhorod National University 16-A, Universytetska str., Uzhhorod, 88015, Ukraine

Keian D. M., Candidate of Medical Sciences Associated Professor, Department of Surgical and Orthopeadical Dentistry Kyiv International University Medical Director University Clinic 49, Lvivska str., Kyiv, 03179, Ukraine 